\title{
NYELAMAK DILAOK : SEBUAH TRADISI SELAMETAN MASYARAKAT PESISIR TANJUNG LUAR LOMBOK TIMUR
}

\author{
Syahdan
}

STIT Palapa Nusantara

syahdankbr@ymail.com

\begin{abstract}
Nyelamak dilaok is a culture that has existed 400 years ago brought by sea travelers from Sulawesi. This tradition is carried out in the village of Tanjung Luar, Keruak District, East Lombok. Regency in the month of Rajab in the Hijri calendar by floating the head of a buffalo on a cluster of rocks in the Tanjung Luar sea. The purpose of this study was to find out how the procedure for implementing nyelamak was carried out from beginning to end. This study also aims to determine the implications of nyelamak dilaok on the community's aqidah, especially for the students of TPQ Al-Mujaddid as the next generation. The data collection procedure used in this study is to collect data through interviews, observation, recording and documentation. Sources of data used are informants who are involved and understand about the tradition, namely traditional leaders, community leaders, religious leaders, village governments, the general public, students of TPQ Al-Mujaddid and books that support the research. While the data analysis method used is a description in the form of a narrative. From the results of the study it can be concluded that if viewed from a social perspective, the tradition of nyelamak dilaok has noble cultural values, but bebind it all, in its implementation, it contradicts the teachings of Islam which has implications for the aqidah of TPQ Al-Mujaddin students
\end{abstract}

Keywords: Dilaok, Implication of Aqidah

\begin{abstract}
Abstrak : Nyelamak dilaok merupakan budaya yang sudah ada 400 tahun silam yang dibawa oleh pengelana laut yang berasal dari Sulawesi. Tradisi ini dilaksanakan di desa Tanjung Luar Kecamatan Keruak Kabupaten Lombok Timur pada bulan Rajab dalam penanggalan Hijriah dengan cara melarung kepala kerbau di atas gugusan batu karang yang ada di laut Tanjung Luar. Tujuan penelitian ini adalah untuk mengetahui bagaimana tata cara pelaksanaan nyelamak dilaok dari awal sampai akhir. Penelitian ini juga bertujuan untuk mengetahui implikasi nyelamak dilaok terhadap aqidah masyarakat terutama terhadap santri TPQ Al-Mujaddid sebagai generasi penerus. Prosedur pengumpulan data yang digunakan dalam penelitian ini adalah dengan mengumpulkan data melalui wawancara, observasi, pencatatan dan dokumentasi. Sumber data yang digunakan adalah para informan yang terlibat dan mengerti tentang tradisi tersebut, yaitu tokoh adat, tokoh masyarakat, tokoh agama, Pemerintah Desa, masyarakat umum, santri TPQ
\end{abstract}

AS-SABIQUN : Jurnal Pendidikan Islam Anak Usia Dini

Volume 3, Nomor 1, Maret 2021; 76-99

https://ejournal.stitpn.ac.id/index.php/assabiqun 
Al-Mujaddid serta buku-buku yang menunjang dalam penelitian tersebut. Sedangkan metode analisis data yang digunakan adalah diskripsi dalam bentuk narasi. Dari hasil penelitian dapat disimpulkan bahwa jika ditinjau dari sosial masyarakat tradisi nyelamak dilaok mempunyai nilai budaya yang luhur tetapi dibalik itu semua dalam pelaksanaannya banyak bertentangan dengan ajaran agama islam yang berimplikasi terhadap aqidah santri TPQ Al-Mujaddin.

Kata Kunci : Nyelamak Dilaok, Implikasi Aqidah

\section{PENDAHULUAN}

Sejarah mencatat nenek moyang bangsa Indonesia adalah para pelaut dan penjelajah samudra yang ulung dan handal. Jiwa penjelajah dan berlayar yang mengakar pada jiwa bangsa Indonesia, telah mengantarkan mereka menjelajahi samudra, meretas pulau dan lautan di nusantara, bahkan melintasi batas-batas negara.

Laut merupakan jalur persebaran utama umat manusia pada masa lampau. Lebih jauh, laut bukan hanya sebagai sarana perhubungan kemaritiman, akan tetapi laut merupakan jalur perkembangan ekonomi, perkembangan tekhnologi navigasi, perkapalan, perkembangan budaya pesisir, angkatan laut dan sebagainya terjadi pada masyarakat maritim.

Lombok merupakan sebuah pulau di kepulauan Sunda Kecil atau Nusa Tenggara yang terpisahkan oleh Selat Lombok dari Bali di sebelat barat dan Selat Alas di sebelah timur dari Sumbawa. Pulau ini kurang lebih bulat bentuknya dengan semacam “ekor" di sisi barat daya yang panjangnya kurang lebih $70 \mathrm{~km}^{2}$. Pulau ini luasnya adalah $4.725 \mathrm{~km}^{2}$ (sedikit lebih kecil daripada Bali) dengan jumlah penduduk pada tahun 2012 kurang lebih 3.722.123 jiwa. ${ }^{1}$

Pada tahun 1360-an dalam babat Negara Kertagama karya Mpu Prapanca Lombok telah berkembang menjadi salah satu bandar yang ramai di bagian timur yang banyak didatangi oleh para pedagang dari berbagai wilayah di nusantara maupun oleh para bandar dagang (Loji) dari negara lain. Keadaan inilah yang membuat Lombok

\footnotetext{
${ }^{1}$ L. Murdi, Jejak Kehidupan Bahari (Sulawesi dan Lombok dalam lintas sejarah maritim), Universtas Negeri Makasar: 2012 Diakses pada tanggal 07-01-2017.
} 
memiliki hubungan dengan bandar-bandar (pelabuhan) lain diseluruh Indonesia terutama dengan Makassar (Sulawesi Selatan).

Makassar dan Lombok (Ampenan saat itu) pada akhir abad ke-16 hingga paruh pertama abad ke-17 menjadi pusat niaga untuk pelaut dan pedagang di Asia dan Eropa dalam komoditas rempah-rempah dan kayu cendana. Perkembangannya inilah yang menempatkan pelabuhan Ampenan sebagai tempat yang strategis di tengah jalur perdagangan panjang antara: Australia-Singapura-India, dan Australia-Manila-Cina. ${ }^{2}$

Perpindahan orang-orang ke berbagai daerah, baik di wilayah Indonesia maupun di luar wilayah Indonesia merupakan tradisi yang telah berlangsung lama. Selain untuk menjelajah juga untuk mencari kehidupan yang layak. berkaitan dengan masalah ekonomi. Sebagai etnis yang memiliki naluri untuk merantau, orang-orang makassar selalu berupaya mencari tempat yang dianggap layak bagi dirinya untuk tinggal, bekerja, bermasyarakat, dan lain-lain. Selama hal tersebut belum dicapai, perantauan tidak akan pernah berakhir.

Keadaan ini sudah berlangsung sejak abad XV dimana orang-orang makassar (Bugis, Mandar dan Bajo) sudah menyebar di pesisir timur Pulau Sumbawa, Lombok, Bali, dan beberapa wilayah lain di indonesia. Mereka memegang peranan penting dalam berbagai bidang dan lapangan kerja, sebagai pedagang, muballiq, bahkan sebagai penguasa.

Beberapa abad kemudian migrasi orang-orang Makassar (Bugis, Bajo, dan Mandar) perkembangannya sangat pesat dalam beberapa decade lampau di Sumbawa, Bali, dan Lombok. Ini tercermin dalam Volkstelling tahun 1930 (Bugis 10.700 orang, Bajo 2.251 orang, dan Mandar 2.295 orang). Jumlah ini adalah akumulasi dari persebaran sebelumnya dalam jumlah yang lebih banyak dimulai pada abad ke-XVI.

Penjelasan di atas hanya sebagian kecil dari gambaran umum persebaran sukusuku yang ada di Sulawesi Selatan, hal ini tidak lain untuk menggambarkan jiwa petualangan masyarakatnya hingga sampai dan menetap di Bumi Sasak. Dengan kata lain, gambaran persebaran mereka di ataslah yang mejadi faktor dalam perkembangannya di Pulau Lombok. Penjelasan di atas untuk membuka pemahaman

2 Adrian B. Lapian, Pelayaran dan Perniagaan Nusantara abad ke-16 dan 17, (Jakarta: Komunias Bambu, 2008), hlm. 57-62 
kita akan hubungan bahari Sulawesi Selatan dengan Pulau Lombok, baik dalam sejarahnya maupun dalam perkembangan prosesnya hingga saat ini. ${ }^{3}$

Penting dicatat juga dalam hal ini adalah perkembangan Islam di Lombok Timur yang diyakini disebarkan melalui jalur perdagangan, baik itu berasal dari pedagangpedagang Makasar, Jawa, maupun Arab. Hal ini dapat diketahui dari minoritasnya ditemukan komunitas Wetu Telu di Lombok Timur. Diperkirakan Islam menjangkau daerah ini disebarkan oleh para pedagang dan nelayan dari Makasar melalui Labuhan Kayangan, Lombok Timur. Itu terlihat dari banyaknya penduduk Lombok Timur yang keturunan Makasar. Islam yang mereka anut disebut dengan Islam Suni. Adapun yang mengistilahkannya dengan Wetu Lima, yakni suatu ajaran yang mengamalkan Islam secara sempurna. Wetu Lima mempercayai bahwa rukun Islam itu ada lima dan harus menjadi tanggung jawab masing-masing pribadi muslim.

Berdasarkan berita yang ada, orang-orang Makassar pada abad ke-16 berhasil menguasai Selaparang, kerajaan orang Sasak Asli. Dibandingkan dengan orang Jawa, orang Makassar lebih berhasil dalam mendakwahkan Islam Sunni. Mereka berhasil mengkonversikan hampir seluruh orang Sasak ke dalam Islam, meskipun kebanyakan mereka masih mencampurkan Islam dengan kepercayaan lokal yang non-Islami.

Berkaitan dengan persebaran Suku Bugis, Mandar dan Bajo dari Sulawesi selatan menurut Negara Kertagama sudah ada sejak permulaan abad ke-14 di Labuhan Lombok. Lebih jauh lagi pada abad ke-16 setelah pelabuhan Ampenan di Lombok Barat, lebihlebih pada abad ke-19 persebarannya telah berkembang pesat. Pada saat itu juga orangorang dari Sulawesi selatan mulai berimigrasi ke pesisir Awang (Lombok Tengah), Labuhan Haji, dan Tanjung Luar (di Lombok Timur). Keberadaan mereka dalam sejarah membawa bahasa serta budaya yang mereka kembangkan di pulau Lombok khususnya di desa Tanjung Luar. ${ }^{4}$

Tanjung Luar merupakan salah satu desa yang ada di Kecamatan Keruak Kabupaten Lombok Timur Nusa Tenggara Barat. Desa ini memiliki luas $106.985 \mathrm{Ha}$ dengan jumlah penduduk sebanyak 9.890 jiwa dari 2.997 kepala keluarga. Tanjung Luar

\footnotetext{
3 Andi Zainal Abidin, Persepsi orang Bugis Makassar tentang Hukum, Negara dan Dunia luar, (Bandung: Alumni,

${ }^{4}$ L. Murdi, Jejak Kehidupan Bahari (Sulawesi dan Lombok dalam lintas sejarah maritim), Universtas Negeri Makasar, 2012

Diakses pada tanggal 07-01-2017.
} 
memiliki tempat pelelangan ikan terbesar di pulau Lombok. Hal ini disebabkan karena sebagian besar (80\%) penduduknya bermata pencaharian sebagai nelayan. Mereka menggantungkan hidup dari hasil laut. Tanjung Luar merupakan desa heterogen yang dihuni oleh berbagai suku dengan bahasa dan budaya yang berbeda-beda, namun mereka tetap hidup berdampingan, rukun, dan damai. Suku mayoritas di Tanjung Luar adalah suku Mandar, Bugis, Bajo (Sama) Makassar, sedangkan suku minoritasnya adalah suku Sasak dan Jawa. ${ }^{5}$

Disebutkan, orang yang pertama kali membawa tradisi nyelamak dilaok ini adalah seorang pengelana laut yang berasal dari Sulawesi Selatan bernama Punggawa Rattung, yaitu keturunan raja-raja Gowa dari garis keturunan Marakdia Palarangan. ${ }^{6}$ Kegiatan atau upacara yang sama hingga saat ini masih dapat dijumpai di beberapa tempat di Sulawesi Selatan seperti Bone, Sanjai, Balanipa dan beberapa daerah lain di Sulawesi yang konon sebelum sampai di Desa Tanjung Luar Lombok Timur, daerahdaerah tersebut pernah disinggahi Punggawa Ratung.

Karena suatu alasan tertentu, Punggawa Rattung berlayar menggunakan perahu dayung seorang diri hingga sampai ke Tanjung Luar. Kemudian perahunya disandarkan di tepi pantai Tanjung Luar, tepatnya di dusun Kampung Toroh Selatan sekarang. Ada pula sumber lain yang menyatakan bahwa Punggawa Rattung pertama kali menyandarkan perahunya di Dusun Kedome (sekarang ini Desa Ketapang Raya) dan tinggal di sana hingga mempunyai keturunan yakni Suku Bajo.

Setelah berpuluh tahun Punggawa Ratung tinggal di Tanjung Luar, timbullah rasa rindu untuk kembali ke kampung halamannya di Sulawesi Selatan. Oleh karena itu, seluruh sanak keluarganya dikumpulkan untuk diberi tahu maksudnya. Dengan berat hati seluruh sanak keluarga Punggawa Rattung melepas kepergiannya yang hanya menggunakan perahu dayung. Tak seberapa jauh dari daratan Punggawa Ratung mengayuh dayung, tiba-tiba dia bersama perahunya hilang bagai ditelan laut, dan di tempat Punggawa Rattung menghilang itu muncullah terumbu karang yang menurut leluhur suku bangsa Bajo adalah penjelmaan dari Punggawa Rattung.

\footnotetext{
5 Data Terbaru Desa Tanjung Luar 2017.

6 Nurlaili, (2009. 44-46) dalam Ida Ayu Komang Sinta Dewi, Pemertahanan Tradisi Petik Laut Oleh Nelayan Hindu dan Islam di Desa Pekukutan Jembrana Bali, (Singaraja: Universitas Pendidikan Ganesha, 2014), hlm. 4.
} 
Beberapa tahun kemudian, datanglah seorang tua dari Sulawesi Selatan mengaku saudara misan Punggawa Rattung yang bernama Mbok Bisu. Anak cucu Punggawa Rattung (Suku Bajo) sangat menghormati Mbok Bisu, mereka mengakui bahwa pengetahuannya di bidang pelayaran dan hal-hal yang berkaitan dengan kegaiban di laut hampir menyamai Punggawa Rattung.

Suatu hari Mbok Bisu ingin melihat tempat terakhir menghilangnya Punggawa Rattung, dan ia pun berpesan kepada anak cucu Punggawa Ratung, jika dirinya tidak kembali dan menghilang jangan dicari kemana-mana. Carilah di sekitar batu itu dan menguburkannya di sana. Setelah itu, berangkatlah Mbok Bisu ke tempat yang dituju, setelah beberapa lama Mbok Bisu pun menghilang di tempat Punggawa Rattung menghilang. Sejak saat itu, masyarakat nelayan suku Mandar, Bajo (Sama), Bugis dan Makassar di Tanjung Luar meyakini bahwa upacara selamatan laut merupakan acara sakral dan di batu itulah selamatan laut atau nyalamak dilaok dengan Niba Tikoloq (melarung kepala kerbau) dilakukan. ${ }^{7}$

Dalam melakukan nyelamak dilaok mereka memotong seekor kerbau, dimana kepala kerbau yang telah dipotong akan dilarung/dilepas ke batu karang yang ada di pesisir pantai Tanjung Luar, sedangkan daging kerbau tersebut dijadikan lauk upacara selamatan dan sebagiannya lagi disedekahkan. Inilah yang menjadi cikal bakal diadakannya selamatan laut (nyelamak dilaok) di Desa Tanjung Luar Kecamatan Keruak.

Bagi masyarakat awwam, budaya nyelamak dilaok berpengaruh besar dalam sendisendi kehidupan mereka. Karena sudah mengakar dalam kehidupan masyarakat, posisi nyelamak dilaok lebih utama dan lebih tinggi dari apapun bahkan melebihi dari ilmu kesehatan (medis), dan mengalahkan ilmu agama (ketuhanan). Menurut mereka, daging kerbau yang dipersembahkan untuk nyelamak dilaok mempunyai kekuatan magis dan khasiat untuk menyembuhkan semua penyakit bagi yang memakannya.

Selain kepercayaan seperti di atas, masih banyak kepercayaan-kepercayaan lain yang mendarah daging dalam kehidupan masyarakat Tanjung Luar yang merupakan bagian-bagian dari tradisi Nyelamak Dilaok, diantaranya adalah acara sengkineh bagi ibu hamil yang mendekati waktu melahirkan, dibantang bagi anak laki-laki yang mau dikhitan,

\footnotetext{
7 Asmayadi, Makalah Sejarah Tanjung Luar (Sejarah yang terkandung dalam upacara Nyelamaq Dilaok), (Tanjung Luar:
} 2012), hlm. 14-15. 
dikatang benah agar terhindar dari penyakit dan bahaya ketika musim penyakit datang, dan masih banyak lainnya. Kepercayaan terhadap acara atau ritual di atas sudah menjadi bagian yang tak terpisahkan dari kehidupan masyarakat Tanjung Luar, dan akan menjadi suatu kebanggaan apabila mereka bisa melakukannya.

Beberapa tokoh agama pernah berusaha untuk menghentikan acara nyelamak dilaok karena dianggap bertentangan dengan ajaran agama, namun usaha itu sia-sia karena masyarakat Tanjung Luar bersikukuh tetap melakukan tradisi nyelamak dilaok dengan alasan ingin mempertahankan dan melestarikan tradisi dan budaya nenek moyang mereka. Namun pada perkembangannya, akhir-akhir ini banyak masyarakat yang mulai faham dan sadar akan dampak dari tradisi dan budaya nyelamak dilaok terutama generasi muda yang berpendidikan, namun tidak sedikit pula dari mereka yang berpendidikan tetap kuat berpegang pada tradisi dan budaya Nyelamak Dilaok. Lalu, bagaimana dengan anak-anak generasi penerus yang ada di Tanjung Luar.

Tradisi nyelamak dilauk diduga memiliki inplikasi terhadap aqidah umat Islam. Maka dalam penelitian ini mencoba mengeksplorasi lebih dalam mengenai tradisi tersebut dengan untuk mengetahui lebih dalam bagaimana pemahaman aqidah masyarakat Tanjung Luar dengan mengambil beberapa responden dari Santri TPQ AlMujaddid Tanjung

Berdasarkan uraian di atas, maka masalah dalam penelitian dapat dirumuskan: 1) Bagaimana prosesi upacara selamatan laut "nyelamak dilaok" yang ada di Desa Tanjung Luar Kecamatan Keruak Kabupaten Lombok Timur Provinsi Nusa Tenggara Barat. 2) Bagaimana Implikasi tradisi "Nyelamak Dilaok" tersebut.

Manfaat yang bisa diperoleh dari penelitian ini antara lain : untuk memperkaya khasanah ilmu pengetahuan tentang "myelamak dilaok" yang ada di Desa Tanjung Luar Kecamatan Keruak Kabupaten Lombok Timur. Diharapkan pula dapat digunakan sebagai informasi penting bagi pemerintah sebagai pelaku kebijakan dalam mengembangkan pariwisata di Lombok Timur khususnya. 


\section{KAJIAN PUSTAKA}

\section{Nyelamak Dilaok}

Nyelamak dalam bahasa Sasak disebut disebut juga nyelamet dan dalam bahasa Indonesia adalah selamatan. Selamatan dalam kamus besar bahasa Indonesia berasal dari kata "selamat" yang artinya 1) terbebas dari bahaya, malapetaka, bencana, terhindar dari bahaya, malapetaka, bencana, tidak kurang satu apapun, tidak mendapat gangguan. 2) tercapai maksud, tidak gagal. 3) doa (ucapan, pernyataan) yang mengandung harapan supaya sejahtera (beruntung). 4) pemberian salam mudah-mudahan dalam keadaan baik (sejahtera, sehat, afiat, dan sebagainya). Jadi nyelamak adalah doa, upacara untuk meminta selamat. Sedangkan Dilaok dalam bahasa Tanjung Luar artinya laut.

Nyelamak dilaok yakni melarung kepala kerbau (Niba Tikolok) ke lokasi batu karang di pesisir laut Tanjung Luar. Nyelamak dilaok (selamatan laut) biasanya dilaksanakan ketika hasil tangkapan laut menurun dan para nelayan sering mendapat musibah (karam dan tenggelam) ditengah laut. Mereka percaya dengan melakukan ritual nyelamak dilaok hasil laut akan melimpah ruah dan tidak ada lagi nelayan yang mendapat musibah di tengah laut.

\section{Aqidah}

Dalam ajaran Islam, aqidah Islam (al-aqidah al-Islamiyab) merupakan keyakinan atas sesuatu yang terdapat dalam apa yang disebut dengan rukun iman, yaitu keyakinan kepada Allah SWT, malaikat-Nya, kitab-kitab-Nya, rasul-rasul-Nya, hari akhir, serta taqdir baik dan buruk.

Secara Bahasa (Etimologi) Kata "'aqidah" diambil dari kata dasar "al-'aqdu" yaitu ar-rabth (ikatan), al-Ibraam (pengesahan), al-ibkam (penguatan), at-tawatstsuq (menjadi kokoh, kuat), asy-syaddu biqumwah (pengikatan dengan kuat), at-tamaasuk (pengokohan) dan al-itsbaatu (penetapan). Di antaranya juga mempunyai arti al-yaqiin (keyakinan) dan al-jąmu (penetapan).

Aqidah artinya ketetapan yang tidak ada keraguan pada orang yang mengambil keputusan. Sedang pengertian aqidah dalam agama maksudnya adalah 
berkaitan dengan keyakinan bukan perbuatan. Seperti aqidah dengan adanya Allah dan diutusnya pada Rasul. Bentuk jamak dari aqidah adalah aqa-id.

Secara Istilah (Terminologi) Aqidah menurut istilah adalah perkara yang wajib dibenarkan oleh hati dan jiwa menjadi tenteram karenanya, sehingga menjadi suatu kenyataan yang teguh dan kokoh, yang tidak tercampuri oleh keraguan dan kebimbangan. Adapun pengertian secara terminologi (istilah) adalah: Syaikh Taqiyuddin An-Nabaniy menyatakan aqidah adalah iman. Iman merupakan pembenaran (keyakinan) yang bersifat pasti (tashdiqu al-jaazim) yang sesuai dengan kenyataan berdasarkan dalil.

Mahmud Syaltouth menyatakan bahwa aqidah merupakan cara pandang keyakinan yang harus diyakini terlebih dahulu sebelum segala perkara yang lainnya dengan suatu keyakinan yang tidak diliputi keraguan dan tidak dipengaruhi oleh kesamaran yang menyerupainya.

Muhammad Husen Abdullah menyatakan aqidah adalah pemikiran yang menyeluruh tentang alam, manusia, kehidupan, serta hubungan semuanya dengan sebelum kehidupan (Sang Pencipta) dan setelah kehidupan (Hari Kiamat), serta tentang hubungan semuanya dengan sebelum dan setelah kehidupan (syari'at dan hisab). ${ }^{8}$

\section{Penelitian Terdahulu}

Penelitian terdahulu pertama yang relevan dengan skripsi ini adalah skripsi yang ditulis oleh Agus Atiq Murtadlo dengan judul Akulturasi Islam dan Budaya Lokal Dalam Tradisi Upacara Sedekah Laut Di Pantai Teluk Penyu Kabupaten Cilacap". Dijelaskan bahwa bagi masyarakat nelayan di pantai Teluk Penyu Cilacap ritual sedekah laut bukan hanya sekedar rutinitas tahunan akan tetapi dijadikan sebagai upacara tradisional yang menyiratkan simbol-simbol kearifan lokal.

\footnotetext{
8 Asef Saipul Hamdi \& Arif Rachman Badrudin, Dasar-dasar Agama Islam, (Yogyakarta: CV. BUDI UTAMA, 2016), hlm. 1-

9 Agus Atiq Murtadlo, Akulturasi Islam dan Budaya Lokal Dalam Tradisi Upacara Sedekah Laut Di Pantai Teluk Penyu Kabupaten Cilacap, (Yogyakarta: UIN Sunan Kalijaga, 2009).
} 2. 
Dalam tulisannya peneliti memaparkan bahwa tradisi upacara sedekah laut merupakan ajaran murni Hindu-Budha, karena pada awalnya bangsa Indonesia termasuk penganut Animisme dan Dinamisme. Tetapi setelah islam masuk ke Indonesia melalui berbagai cara, banyak sekali unsur-unsur atau nuansa keislaman yang masuk ke dalam tradisi upacara sedekah laut tersebut.

Mencermati pendapat di atas, saya tidak sependapat dengan apa yang disampaikan oleh peneliti karena bagaimana mungkin agama islam yang hanya mengenal satu tuhan bisa menyatu dengan agama lain yang mempercayai lebih dari satu tuhan.

Penelitian terdahulu kedua yang relevan dengan penelitian ini adalah skripsi yang ditulis Ali Wildan dengan judul Tradisi Sedekah Laut Dalam Etika Ekologi Jawa ${ }^{10}$. Dari hasil penelitiannya dijelaskan bahwa sedekah laut di Desa Gempolsewu selain sebagai ritual kebudayaan juga sebagai sarana untuk melestarikan Ekologi dan Ekosistem laut karena secara tidak langsung ikan, hewan dan biota laut akan memakan sesaji tersebut. Selain itu, apabila Ekosistem laut rusak maka manusia sendiri yang akan merasakan dampaknya.

Dalam hal ini saya sangat setuju dengan apa yang dipaparkan oleh peneliti, tetapi dilain hal saya tidak sependapat dengan peneliti. Dijelaskan

bahwa dalam tradisi ini masih ada kepercayaan tentang penguasa laut (Joko Moro) yang meminta sesajen, dan apabila sesajen tidak lengkap maka ia akan marah. Itu artinya mereka masih percaya adanya kekuatan dan penguasa selain Allah padahal peneliti sendiri menjelaska Al-qur'an surat Al-Isro' bahwa iblis dan bala tentaranya hanya ingi menyesatkan anak cucu keturuna adam sampai hari kiamat, tapi mengapa peneliti dalam kesimpulannya menyatakan bahwa upaca tradisi selamata laut tidak bertentangan dengan ajaran islam.

Penelitian terdahulu ke tiga yang relevan dengan penelitian ini adalah artikel yang ditulis oleh Ida Ayu Komang Sintia Dewi dengan judul Pemertahanan Tradisi

10 Ali Wildan, Tradisi Sedeka Laut Dalam Etika Ekologi Jawa, (Semarang, UIN Walisongo, 2015) 
Budaya Petik Laut Oleb Nelayan Hindu dn Islam di Desa Pekukatan Jembrana Bali. ${ }^{11}$ Dari hasil penelitiannya dijelaskan bahwa Di Jembrana Bali tradisi petik laut masih dipertahankan oleh masyarakat setempat karena tradisi tersebut merupakan wadah, sarana atau tempat para nelayan atau warga pesisir untuk bersilaturrahmi dan berkumpul walaupun agama mereka berbeda. Selain itu, tujuan dipertahankannya tradisi ini adalah untuk memberikan pelajaran dan pengajaran kepada generasi muda yang minatnya mulai berkurang untuk tetap melestarikan tradisi ini.

Dalam tulisannya disimpulkan bahwa tradisi petik laut merupakan kegiatan agama yang tujuannya untuk memberikan penghormatan terhadap seorang pelaut Sulawesi Selatan bernama punggawa ratung yang merupakan keturunan dari raja-raja goa dari garis keturunan Marakdia Malarangan. Akan tetapi, dalam melaksanakan tradisi petik laut mereka selalu menanamkan harapan akan keselamatan dan rizki yang berlimpah.

\section{HASIL DAN PEMBAHASAN}

\section{Pelaksanaan Nyelamak Dilaok}

Sebelum dilaksanakannnya prosesi nyelamak dilaok terlebih dahulu diadakan rapat tokoh adat, tokoh masyarakat, dan Pemerintah Desa Tanjung Luar untuk membentuk kepanitiaan yang bertugas mempersiapkan segala sesuatu yang dibutuhkan dalam nyelamak dilaok. Setelah kepanitiaan terbentuk maka panitia tersebut akan mengadakan rapat kembali untuk menetapkan beberapa hal, antara lain: Menetapkan siapa yang akan menjadi Sandro (Mangku) laki-laki dan Sandro perempuan, kemudian yang akan menjadi pangalantiq (tukang pencak silat), menjadi Bone-bone, dimana Sarapo (rumah adat) akan didirikan tanggal berapa Sarapo akan dibuat, kapan (tanggal berapa) Ngaririq kerbau (membawa kerbau keliling Desa) akan dilaksanakan dan menurut informasi biasanyadilaksanakan tanggal 17-19 bulan Rajab, kemudian tanggal berapa pelaksanaan malaggaq tikolog atau melarung kepala kerbau, dan menurut

\footnotetext{
${ }^{11}$ Ida Ayu Komang Sintia Dewi, Pemertahanan Tradisi Budaya Petik Lut Oleh Nelayan Hindu dan Islam di Desa Pekutatan Jembrana Bali. (Singaraja, Universita Pendidikan Ganesha, 2014).
} 
informasi pula ini niasanya dilaksanakan tanggal 20 Rajab, dan siapa saja yang akan bertugas mengumpulkan benda-benda pusaka, seperti: Ula-ula atau panjipanji (ula-ula putih adalah ula-ula suku Bajo, uning suku Mandar, hitam suku Bugis, dan merah suku Makassar). Bujjaq Bandrangah dan Bujjaq sipiq. Bendabenda pusaka peninggalan suku Bajo.

Berikutnya yaitu siapa yang akan bertugas utuk membeli dan bertugas untuk mengumpulkan bahan-bahan dan barang-barang berupa tujuh jenis air masing-masing satu liter, yaitu, air hujan yang turun pertama kali pada tahun itu (tugas tokoh adat), air sumur masjid, air sumur tua, ait sungai, air embun, air muara sungai, dan air laut pelabuhan. Kemudian enselang bau (minyak wangi) delapan botol, bambu kuning, langir sama, parai bente, ketan hitam, ketan putih dan ketan merah, beras putih, beras hitam, dan beras kuning.

Ditambah pula berupa benang tujuh warna (putih, kuning, hitam merah, biru hijau dan coklat), daun lontar secukupnya, tebu sala (tebu untuk membuat gula), boloq tallah (bambu yang bukunya berhadapan), kakul karaeng (keben dalam bahasa sasak) tujuh buah dari yang berukuran besar sampai yang berukuran kecil dan $\mathrm{s}^{12}$ egala jenis hasil laut.

Penetapan sandro berdasarkan garis keturunan dan pengetahuan mereka tentang nyelamak dilaok, biasanya yang akan menjadi sandro adalah orang suku Bajo. Setelah rapat menentukan siapa yang akan menjadi sandro barulah pengumpulan barang-barang dan bahan-bahan untuk perlengkapan nyelamak dilaok dan pembangunan sarapo dilakukan. Bersamaan dengan pengumpulan bahan-bahan dan barang-barang yang dibutuhkan untuk nyelamak dilaok, panitia, tokoh adat, tokoh masyarakat dan masyarakat secara umum bergotong-royong bersama-sama membangun rumah adat (sarapo), dimana sarapo dibangun menggunakan bahan-bahan yang terbuat dari kayu, tidak boleh menggunakan bahan lain dan biasanya lokasi Sarapo dekat dengan pantai. Setelah Sarapo selesai dibangun semua bahan-bahan dan barang-barang yang telah dikumpulkan akan dibawa ke Sarapo untuk di cek kembali apakah benar-benar sudah komplit atau belum, apabila belum lengkap maka akan dicari lagi untuk melengkapinya. 
Setelah semuanya dianggap lengkap, barulah Sandro (Mangku) yang telah ditunjuk untuk memimpin nyelamak dilaok dengan ditemani oleh tokoh adat pergi membeli kerbau untuk dijadikan persembahan. Minimal 5 (lima) hari sebelum ngeririk dilakukan semua keperluan dan kebutuhan untuk nyelamak dilaok harus sudah lengkap. Penggunaan kerbau dalam nyelamak dilaok membuktikan bahwa budaya ini berasal dari Toraja (Sulawesi).

Anggaran dana yang digunakan dalam acara nyelamak dilaok berasal dari iuran masyarakat, namun beberapa tahun terakhir dana yang digunakan dalam nyelamak dilaok berasal dari Instansi Pemerintah (Dinas Kebudayaan dan Pariwisata), sumbangan perusahaan (PT. New Mount Nusa Tenggara) dan sumbangan partai politik yang ingin mendapatkan suara dan dukungan dalam pemilihan. $^{13}$

Kerbau yang akan dibeli bukan sembarang kerbau, kerbau tersebut harus mau untuk dijadikan persembahan dalam acara Nyelamak Dilaok setelah melakukan komunikasi dengan Sandro dan kerbau tersebut tidak

boleh ditawar dalam proses jual-beli. Setelah proses jual-beli selesai kerbau langsung dibawa ke Sarapo untuk dimandikan kelaut kemudian diistirahatkan ditempat khusus sebelum kerbau Diririq (diarak keliling) Desa Tanjung Luar selama tiga hari berturut-turut.

Sebelum proses Ngeririk kerbau (mengarak kerbau) dilakukan, biasanya akan dipasang bendera empat warna (putih, kuning, hitam, dan merah) pada empat penjuru angin untuk memberitahukan kepada masyarakat bahwa acara nyelamak dilaok akan dilaksanakan. Selain itu, Sandro akan Muke dilaok (meminta izin) untuk melaksanakan ritual nyelamak dilaok, tokoh adat dan tokoh masyarakat akan mengadakan tasyakkuran (Al-barzanji dan dzikiran) bersama di Sarapo pada pagi hari dengan membuat bubur putih dan pada sore harinya semua orang (suku bajo, mandar, bugis dan makassar) yang akan terlibat dalam ngeririk kerbau akan dikumpulkan untuk membagi tugas masing-masing.

Jika semua sudah dianggap siap barulah proses ngeririk kerbau dilakukan. Biasanya dilaksanakan pada tanggal 17-19 karena pada tanggal

13

Hasil wawancara dengan ketua panitia nyelamak dilaok tabun 2015 (Mukti Ali/ KADES sekarang). Wawancara dilakukan pada tanggal 02 september 2017 jam 20.00 wita. 
itu air laut sore sedang surut. Sebelum kerbau keluar dari kandang khusus yang ada di sebelah sarapo, pengelantik (petugas pencak silat) akan memainkan silat sebagai proses awal sebelum kerbau dibawa keliling kampung. Selain itu, pada empat penjuru angin kerbau akan diberhentikan sejenak kemudian pengelantik juga akan memainkan pencak silatnya. Dalam proses ngeririk kerbau hanya empat suku (suku bajo, mandar, bugis dan makassar) saja yang diperbolehkan ikut dalam barisan pengiring, apabila ada dalam barisan pengiring itu suku lain selain suku yang empat maka akan terjadi kedongkoang (seperti kesurupan) dan bisa menjadi sebab tidak akan berjalan dengan baiknya acara nyelamak dilaok. ${ }^{14}$

Setelah diririk selama tiga hari, sekitar jam 21.00 wita barulah kerbau disembelih dipinggir pantai, darahnya akan diambil sebagai campuran Bantang (sembeq dalam bahasa sasak) untuk dipakaikan kepada semua orang yang akan terlibat pada proses Niba Tikoloq (melarung kepala kerbau) pada besok paginya. Setelah kerbau mati, kepalanya akan dibawa ke sarapo untuk dibersihkan kemudian akan diberikan hiasan berupa benang emas pada gigi dan kedua tanduknya. Selanjutnya kepala kerbau akan dibungkus dengan kain putih, diukup dengan menyan sambil dinyanyikan nyanyian asal-usul pelaut. Sepanjang malam suara melengking gandah pencak dan serone mengiringi proses tersebut yang membuat suasana malam itu diselimuti aura mistik.

Pada jam 03.00 wita kepala kerbau yang telah diukup tersebut akan dimasukkan kedalam rakit kecil yang telah dipersiapkan sebagai tempat kepala kerbau untuk dilarung. Bersamaan dengan itu di dalam rakit tersebut juga diisi dengan jajanan berbentuk semua jenis ikan yang ada di laut. Setelah semua selesai dan siap sekitar jam 08.00 wita atau setelah tamu undangan datang barulah proses Niba Tikoloq akan dilakukan.

Pertama-tama kepala kerbau yang ada di dalam rakit kecil tersebut akan dimainkan pencak silat setelah turun dari tangga sarapo, sebelum naik ke atas sampan yang akan membawa kepala kerbau tersebut ke lokasi batu karang, kepala kerbau itu kembali dimainkan pencak silat, dan sepanjang perjalanan ke

14 
lokasi batu karang itu suara gandah pencak dan serone akan tetap mengiringi proses tersebut.

Setelah sampai ke lokasi batu karang tempat kepala kerbau akan dilarung, sampan yang membawa kepala kerbau itu akan berputar mengitari batu karang tersebut sebanyak tiga kali. Setelah selesai berputar barulah rakit kecil yang berisi kepala kerbau dan jajanan berbentuk semua jenis ikan itu akan dilarung oleh sandro di atas batu karang besar yang menurut kepercayaan masyarakat Tanjung Luar batu karang besar tersebut adalah tempat bersemayam Mbo Balo (nenek moyang) mereka.

Setelah proses Niba Tikoloq selesai, maka acara siram-siraman dilakukan oleh masyarakat yang ada di laut, kemudian akan di ikuti oleh masyarakat yang ada di darat sebagai bentuk ekspresi kebahagiaan karena telah selesainya seluruh prosesi Nyelamak Dilaok, sedangkan Sandro akan kembali ke sarapo dengan disambut permainan pencak silat sebagai pemberitahuan bahwa acara nyelamak dilaok telah selesai.

Biasanya setelah acara Nyelamak Dilaok selesai sandro akan ngapuk dilaok sekaligus sebagai larangan kepada para nelayan untuk tidak melaut selama tiga hari tiga malam, jika ada yang melanggar aturan tersebut maka akan dikenakan sanksi (hukuman). Selama tiga hari tersebut tokoh adat dan tokoh masyarakat mengadakan dzikiran dan do'a bersama di sarapo untuk meminta keselamatan dan rizki yang melimpah. Setelah tiga hari barulah sandro akan muke dilaok lagi artinya nelayan sudah diperbolehkan untuk melaut dan menangkap ikan. ${ }^{15}$

\section{Pandangan Masyarakat Tentang Nyelamak Dilaok}

Menurut sebagian masyarakat Tanjung Luar, Nyelamak dilaok adalah tradisi turun-temurun yang sudah mendarah daging dalam kehidupan masyarakat pendukungnya, meskipun penuh pro-kontra antara pendukung dan penentangnya nyelamak dilaok tetap bertahan di Tanjung Luar dengan berbagai alasan. Menurut salah seorang informan, bahwa jika ditinjau dari

15

Wawancara dengan Bapak Abdul Hamid (Tokoh Masyarakat/ Tokoh adat/ Anggota BPD). Zainuddin, S. Pd. (Staf Desa Tanjung Luar) Wawancara dilakukan pada tanggal 06 september 2017 jam 16.00 wita. 
aspek sosial kemasyarakatan (budaya), nyelamak dilaok mempunyai peran penting dalam membina persatuan dan kesatuan masyarakat. Apabila akan diadakannya nyelamak dilaok, maka dari jauh-jauh hari masyarakat akan bersama-sama mengeluarkan uang(iuran) untuk membiayai acara nyelamak dilaok. Setelah uang terkumpul maka masyarakat akan bersama-sama membangun sarapo (rumah adat) sebagai tempat (stand) untuk merencanakan dan mempersiapkan acara. Ini mencerminkan kerukunan antar warga masyarakat yang heterogen yang ada di Tanjung Luar, meskipun dalamsejarah bahwa nenek moyang suku bajo (keturunan Sultan Hasanuddin) memiliki dendam atau permusuhan dengan nenek moyang suku Bugis (keturunan Aru Palaka) karena telah membantu VOC pada tahun 1666 menyerang makassar. Namun dengan acara nyelamak dilaok permusuhan atau dendam itu bisa hilang.

Karena dinilai sebagai tempat yang sakral, gugusan batu karang tempat kepala kerbau dilarung tersebut tidak berani diganggu dan dirusak oleh masyarakat, satu orangpun tidak ada yang berani merusaknya sehingga ikannya tetap utuh disana. Artinya secara tidak langsung nyelamak dilaok berperan dalam menjaga kelestarian ekosistem laut. Selain itu, setelah Niba Tikolog nelayan dilarang melaut dan menangkap ikan selama tiga hari tiga malam meninggalkan pesan

bahwa laut perlu close season (istirahat dari aktivitas penangkapan) untuk memberikan kesempatan kepada ikan-ikan untuk bertelur dan berkembang biak. ${ }^{16}$

Selanjutnya Nyelamak dilaok ditinjau dari aspek Agama dalam hal ini agama islam menurut pandangan sebagian masyarakat Tanjung Luar, bahwa dibalik nilai-nilai positif yang terselubung dalam acara nyelamak dilaok jika ditinjau dari sudut pandang agama banyak bertentangan dengan ajaran agama Islam. Kajian dari sudut pandang agama dipandang perlu karena selain sebagai manusia yang berbudaya, kita juga adalah manusia yang beragama,

16

Hasil wawancara dengan Bapak Saifulloh (Tokoh Adat/ Tokoh Lintas Agama). Wawancara dilakukan pada tanggal 07 September 2017 jam 20.00 wita. 
dimana agama inilah yang menentukan selamat atau tidaknya kita di dunia maupun di akhirat.

Pada ritual muke dilaok (meminta izin untuk melakukan nyelamak dilaok) sandro meminta izin kepada makhluk penunggu laut untuk melakukan acara nyelamak dilaok, padahal langit dan bumi beserta isinya termasuk laut adalah ciptaan dan kepunyaan Allah SWT, tidak seharusnya kita meminta apapun kepada selain daripada-Nya. Perbuatan ini menurut sebagian masyarakat Tanjung Luar melanggar hak Allah SWT sebagai pencipta, penguasa, dan pengatur alam semesta. ${ }^{17}$ Dalam Al-qur'an Allah SWT berfirman:

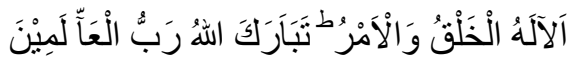

Artinya: "Ingatlah yang menciptakan dan memerintah hanya bak. Allah, maha suci Allah, Tuban semesta alam” (Q.S. Al-A'raf: 54).

Sebelum proses ngeririk kerban dimulai pada hari pertama biasanya sandro dan semua yang ikut terlibat dalam barisan pengeririk akan menggunakan gelang yang terbuat dari benang tujuh warna, gelang tersebut tidak boleh dilepas sampai gelang itu lepas sendiri. Selain menggunakan gelang benang, setiap hari selama tiga hari sebelum ngeririk kerbau dimulai mereka akan dibantang (sembeq dalam bahasa sasak) dan pada hari puncak acara ketika kepala kerbau akan dilarung mereka akan dibantang dengan campuran darah kerbau tersebut. Tujuannya agar mbo balo mengenali mereka, agar mereka terhindar dari penyakit, dijauhkan dari marabahaya dan agar mereka tidak diganggu oleh jin (pengusir setan). Apa yang mereka lakukan ini termasuk dalam kategori syirik khauf (takut). ${ }^{18}$ Allah SWT berfirman:

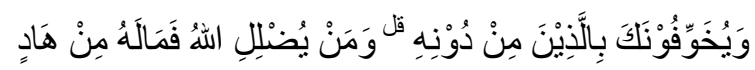

Artinya: Mereka menakut-nakutimu dengan sesembahan yang selain Dia. Barang siapa yang dibiarkan sesat oleh Alloh maka tidak seorang pun yang dapat memberi petunjuk kepadanya. (Q.S. Az-Zumar: 36).

Abu Hafizhah Irfan, M.Si, Ensiklopedia Aqidab Islam. (2016, Pasuruan, Pustaka Al-Bayyinah). hlm 16

Abu Ihsan Al-Atsari. Artikel Syirik dan macam-macamnya. 2004. http:// www. vbaitullah. or. id. hlm 9 
Orang Arab dahulu sering memakaikan untaian kalung atau gelang kepada anak-anaknya agar terlindung dari gangguan setan, ini disebut dengan Tamimah. Menurut Al-Mundziri Tamimah adalah untaian kalung atau gelang yang dipakai guna mengusir penyakit, jin dan marabahaya. Keyakinan terhadap tamimah itu adalah kejahilan dan kesesatan, sebab tidak ada suatu apapun yang dapat mendatangkan atau menghalangi sesuatu kecuali Allah SWT. ${ }^{19}$ Dalam sebuah hadits shahih yang diriwayatkan oleh Ahmad, Rasulullah SAW bersabda yang artinya: "Barang siapa yang menggunakan Tamimah sesungguhnya dia telah musyrik.".

Setelah proses ngerirk kerbau selama tiga hari berturut-turut, barulah pada malam harinya sekitar jam 21.00 wita kerbau akan disembelih di pinggir laut. Darah kerbau yang keluar akan diambil untuk digunakan sebagai campuran bantang dan digunakan untuk menulis kalimat syahadat. Setelah kerbau mati, barulah kepalanya akan diambil dan dibersihkan kemudian dibawa ke sarapo untuk dihias tanduk dan giginya dengan benang emas, yang selanjutnya kepala kerbau tersebut akan diumoh (diukup) dengan dupa dan menyan semalaman. Menurut pengakuan salah seorang reporter CNN kepada الااله masyarakat yang menemaninya meliput, ia mengaku ngeri melihat lafadz ditulis pada kain putih dengan menggunakan darah kerbau. Hal ini dibenarkan oleh tokoh lain yang terlibat dalam proses tersebut.

Ditinjau dari sudut pandang manapun menurut seorang informan bahwa penulisan lafadz tauhid dengan menggunakan darah kerbau tersebut adalah suatu penghinaan terhadap agama terutama kepada Allah dan RasulNya. Allah SWT yang maha esa, yang maha kuasa, yang maha suci, pencipta langit dan bumi beserta rasul-Nya yang Agung asma'-Nya ditulis dengan menggunakan darah binatang (kerbau) yang dalam agama islam darah termasuk dalam najis Mutawasithoh. ${ }^{20}$ Perbuatan ini sangat bertentangan dengan ajaran Islam. Selain itu penggunaan dupa atau kemenyan dalam proses 
ngumoh secara tidak langsung akan mengundang datangnya bangsa jin untuk ikut campur dalam proses tersebut. Allah SWT berfirman:

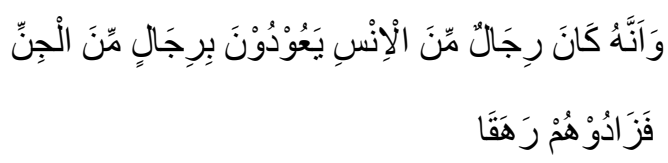

Artinya: Dan sesunggubnya ada beberapa orang laki-laki dari kalangan manusia yang meminta perlindungan kepada beberapa laki-laki dari jin, tetapi mereka (jin) menjadikan mereka (manusia) bertambah sesat. (Q.S. Jin: 6).

Imam Ibnu Qoyyim mengatakan "siapa yang menyembelih binatang diperuntukkan bagi setan, meminta-minta kepada setan, meminta perlindungan kepada setan dan mendekatkan diri kepada setan dengan melakukan apa yang disukai oleh setan, berarti ia telah menyembah setan, sekalipun ia tidak membahasakan hal itu sebagai penyembahan dan hanya membahasakan setan sebagai khadam. Tetapi sebenarnya, justru setanlah yang menjadikannya sebagai khadam bagi setan. Akbirnya ia menjadi khadam dan penyembah setan". ${ }^{39}$

Inti dari proses nyelamak dilaok atau nyelamak pelabuang adalah niba tikoloq (melarung kepala kerbau) dimana proses ini akan dilakukan pada gugusan terumbu karang yang ada disekitaran pantai Tanjung Luar, kurang lebih sekitar 100 meter dari pinggir pantai Dusun Kampung Koko. Pada proses ini, terdapat perbedaan antara sandro yang satu dengan sandro lainnya. Salah satu sandro mengatakan, ketika akan melarung kepala kerbau di atas gugusan batu karang tersebut kita melepasnya seperti biasa tanpa ada siapapun yang menerimanya. Jika kita telaah ini termasuk perbuatan sia-sia karena membuang makanan tanpa alasan yang jelas (Mubaz:ir.$^{21}$

Berbeda dengan sandro yang lainnya, ketika akan melarung kepala kerbau tersebut ada sesosok makhluk yang tidak mau disebut namanya menerima kepala kerbau tersebut, seperti ada ijab-qabul antara sandro dengan makhluk tersebut, makhluk tersebut biasanya oleh sandro disebut Tomanuroh (orang yang diturunkan). Menurutnya, apabila kepala kerbau tersebut diterima

21

Wawancara dengan Dg. H. Ahmad, Sandro Nyelamak Dilaok tahun 2012. Wawancara dilakukan pada tanggal 15 september 2017 jam 16.30 wita. 
oleh makhluk itu maka hasil laut akan melimpah, nelayan tidak akan mendapat musibah ditengah laut dan nelayan akan dijauh dari penyakit dan marabahaya. Dan apabila kepala kerbau tersebut tidak diterima oleh makhluk itu maka akan terjadi sebaliknya, hasil laut akan berkurang, nelayan akan sering mendapat musibah ditengah laut dan penyakit akan banyak melanda masyarakat.

Dalam pandangan sebagian masyarakat Tanjung Luar bahwa jiika dikaji perbuatan ini masuk dalam syirik besar dalam bentuk do'a yaitu selain meminta kepada Allah SWT, ia juga meminta kepada Selain Allah SWT, karena do'a juga dapat bermakna ibadah (penyembahan) dan Allah SWT sangat melarang perbuatan ini. Allah SWT berfirman:

$$
\text { فَلاَ تَذْ عُوْْا مَعَ اللهِهِ اَحَدًا }
$$

Artinya: Maka janganlah kamu berdo'a (beribadab/ menyembab) kepada selain Allah (Q.S. Jin: 18).

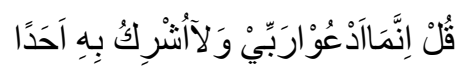

Artinya: Katakanlah (Wahai Muhammad) sesunggubnya aku berdo'a

Selanjutnya, setelah proses niba tikolok selesai nelayan akan dilarang melaut selama tiga hari tiga malam, oleh sandro-sandro terdahulu biasanya digunakan untuk Ngingidah. Ngingidah dilakukan ditengah-tengah laut antara laut Tanjung Luar dengan Labuhan Haji dengan cara mencelupkan tangan sampai bahunya sambil berteriak dengan mengucapkan kata-kata berikut "Wahai malaikat Ismail, wahai Nabi Khidir, wahai Abul Abbas. Aku anak Tuban, mewakilkan kepada kalian untuk membawa masuk ikan-ikan yang ada dilaut lepas sana untuk masuk ke perairan Tanjung Luar”.

Sandro-sandro dahulu kata salah seorang informan, memang terkenal dengan ilmunya, seperti merubah sampah menjadi ikan, menjaring ikan dibawah rumah, memancing ikan didalam kendi air minum, dan masih banyak lainnya. Perkataan dan perbuatan ini jelas-jelas kesyirikan yang sangat nyata, namun karena kejahilannya mereka menganggap perbuatan ini biasa-biasa saja 
dan tidak ada pengaruhnya pada aqidah dan keimanan mereka. Allah SWT berfirman:

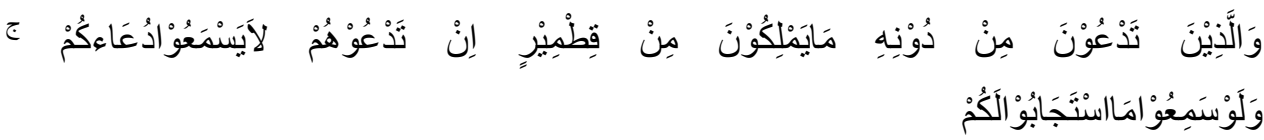

Artinya: Dan orang-orangyang kamu seru (sembab) selain Allab tidak mempunyai apaapa walaupun setipis kulit ari. Jika kamu menyeru mereka, mereka tidak mendengar suaramu, dan sekiranya mereka mendengar, mereka juga tidak memperkenankan permintaanmu. (Q.S. faatir: 13-14).

\section{Implikasi Terhadap Aqidah Islamiyah}

Berdasarkan data data yang diperoleh dari laporan penelitian yang dilakukan oleh Supriadi dengan mengambiil salah satu subjek yaitu TPQ AlMujaddid yang ada di Tanjung Luar menyebutkan bahwa secara tidak langsung nyelamak dilaok mempunyai dampak terhadap aqidah santri TPQ Al-Mujaddid, hal tersebut terlihat dari beberapa santri yang kesehariannya ketika datang ngaji sering menggunakan Tamimah. Menurut pengakuan mereka, gelang atau kalung itu merupakan milik mbo balo yang digunakan sebagai obat dan perlindungan dari marabahaya.

Selain itu, cerita-cerita yang mereka dengar tentang mbo balo membuat mereka lebih takut dan taat kepadanya dari pada mereka takut dan taat kepada Allah SWT. Setiap mereka akan ke laut menjelang maghrib mereka akan mengucapkan salam kepada mbo balo agar mereka tidak diganggu karena menurut cerita orang-orang tua mereka, kalau kita tidak mengucapkan salam mbo bute, mbo bisu dan mbo kerukku (nama-nama mbo balo yang ada di pinggir pantai) tidak akan mengenali dan akan menabrak mereka (kesambet) bahkan ada yang sampai langsung mati di tempat. Takut kepada selain Allah SWT baik berupa jin, orang yang telah mati atau apapun dengan keyakinan bahwa mereka 
mampu mendatangkan mudharat, maka ini termasuk kategori syirik khauf (khauf sirri) yang harus dihindari. ${ }^{22}$ Allah SWT berfirman:

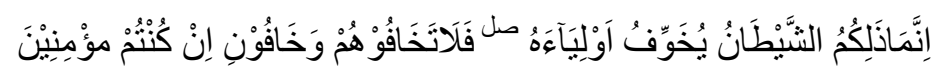

Artinya: Sesunggubnya mereka hanyalah setan yang menakut-nakuti kamu dengan teman-teman setianya, karena itu janganlah kamu takut kepada mereka, takutlah kamu kepada-Ku, jika kamu benar-benar orang beriman. (Q.S. AliImran: 175).

Karena begitu pentingnya masalah aqidah dalam kehidupan beragama terutama bagi generasi penerus yang ada di TPQ Al-Mujaddid, menurut sebagian masyarakat setempat yang sudah mengaji atau memahamim agama, memberikan beberapa yang perlu diajarkan dan tanamkan agar para santri mengerti dan memahami konsep ketuhanan (Tauhid) yang benar yaitu : a) .mennamkan keyakinan dengan sepenuh hati bahwa Allah SWT sebagai pencipta, pemberi rizki, yang menghidupkan, yang mematikan, yang memberi manfaat dan mudharat, dan yang mengatur segala urusan (Tauhid Rububiyah). b). Mendidik para santri agar beribadah hanya kepada Allah SWT dan mengingkari Thagut. Sebagaimana yang difirmankan Allah dalam banyak ayat al-Qur'an, serta memberikan pemahaman tentang perbuatan syirik agar kita terhindar dari perbuatan tersebut

\section{KESIMPULAN}

Nyelamak Dilaok di Desa Tanjung Luar merupakan tradisi turun-temurun yang masih dipertahankan sampai sekarang. Dalam pelaksanaanya banyak nilai-nilai luhur (positif) yang terkandung dalam tradisi Nyelamak Dilaok tersebut, seperti semangat gotong royong dalam membangun Sarapo, kerjasama dalam mengumpulkan dana, kebersamaan dalam melaksanakan acara, bersatu dalam menjaga dan menghindari larangan-larangan selama acara Nyelamak Dilaok dilaksanakan dan lain-lain.

\footnotetext{
22

Abu Ihsan Al-Atsari. Artikel Syirik dan macam-macamnya. 2004. http:// www. vbaitullah. or. id. hlm 10
} 
Di lain sisi pelaksanaan Nyelamak Dilaok terdapat hal-hal yang sepertinya tidak sesuaai syari'at Islam Islam yang menjadi anutan masyarakat seetempat, sebagaimana penutuuran beberapa iiforman bahkan mengarah kepada perbuatan syirik dengan mencontohkannya seperti memakai Tamimah selama acara Nyelamak Dilaok, melakukan ijab-qabul dengan jin laut sampai melakukan Ngingidah.

Terhadap santri TPQ Al-Mujaddid adanya beberapa santri yang keseharian memakai Tamimah, yang mereka yakini sebagai milik Mbo Balo yang dapat menjaga dan melindungi mereka dari marabaya. Selain itu setiap akan ke laut mereka biasanya memberikan salam kepada Mbo Balo sebagai penghormatan dan perkenalan agar mereka dikenali dan tidak diganggu oleh jin laut lainnya. Pemahaman seperti ini didapat dari orang tua mereka dan masyarakat sekitar yang masih teguh memegang tradisi Nyelamak Dilaok, ha-hak tersebut sebagai indikasi adanya implikasi tradisi Nyelamak Dilaok terhadap aqidah masyarakat,

\section{SARAN}

1. Dalam menghadapi perkembangan jaman yang semakin pesat diharapkan kepada semua pihak terutama generasi muda untuk menjadikan aqidah sebagai filter sekaligus tolak ukur untuk menerima segala macam kebudayaan yang ada disekitar kita.

2. Kepada tokoh agama diharapkan untuk lebih intens memberikan pencerahan tentang keagamaan kepada masyarakat Tanjung Luar agar memamahi aqidah yang benar.

\section{DAFTAR PUSTAKA}

Abidin, Andi Zaenal, 1983. Persepsi Orang Bugis Makassar Tentang Hukum, Negara dan Dunia Luar. Yogyakarta: Alumni.

Ahnan, Maftuh. 1990. Risalah Shalat Lengkap. Surabaya, Bintang Usaha Jaya.

Al-atsari, Abu Ihsan. 2004. Artikel Syirik dan Macam-macamnya. http//:www. Vbaitullah. or. Id. Diakses pada tanggal 20/08/2017.

Ardbi21. Blogspot.com/2012/10/ makalah aqidah islam. Diakses pada tgl 05/12/2016. 
Asifuddin, Ahmad faiz. 2004. Artikel Contoh-contoh Kemusyirikan yang Membudaya. http//:www. Vbaitullah. or. id. Diakses pada tanggal 20/08/2017.

Asmayadi, 2012. Sejarah Tanjung Luar (Sejarah Yang Terkandung Di Dalam Upacara Nyelamak Dilaok), Tanjung Luar. Data terbaru Desa Tanjung Luar 2017.

Departemen Agama RI, 2004. Al-qur'an dan Terjemahnya. Jakarta: PT. Syaamil Cipta Media.

Hamdi, Asef Saiful \& Arif Rahman Badrudin, 2016. Dasar- Dasar Agama Islam. Yogyakarta: CV. BUDI UTAMA.

bttp:// murdilalu. Wordpress.com/2012/12/25/ Jejak kehidupan bahari (Sulawesi dan Lombok dalam lintas sejarah maritim). Diakses pada tgl 25/11/2016.

http:// id-id./ notes/ mencari cahaya sunnah/ pengertian dan kedudukan aqidah dalam islam. Diakses pada tgl 05/12/2016.

Irfan, Abu Hafizhah, M. Si. 2016. Ensiklopedia Aqidah Islam. Pasuruan, Pustaka Albayyinah.

Kartono, Kartini, 1996. Pengantar Metodologi Riset Sosial. Bandung: CV. Bandar Maju.

Lapian, Adrian B, 2008. Pelayaran dan Perniagaan Nusantara Abad 16 \& 17. Jakarta: Komunias Bambu.

Lembaga LITBANG, 2003. Aqidah Ablussunnah Waljama'ah. Jakarta. Daarul fatwa.

Lomboknews.com/2007/07/18/ nyelamak dilaok di tanjung luar. Diakses pada tgl 25/11/2016.

Ahnan, Maftuh. 1990. Risalah Shalat Lengkap. Surabaya, Bintang Usaha Jaya.

Moleong, J. Lexy. 2008. Metodologi penelitian dengan kualitatif. Bandung: PT. Remaja Rosdakarya.

Netra, Ida Bagus. 1977. Metodologi Penelitian. Singaraja: Biro penerbit FKIP Udayana.

Raco, J. R. ME, M. Sc., 2010 Metode Penelitian Kualitatif. Jakarta: PT. Gramedia Widiasarana Indonsia.

Tim Redaksi Kamus Bahasa Indonesia, 2008. Kamus Besar Bahasa Indonesia. Jakarta: Pusat Bahasa Departemen Pendidikan Nasional. 